\begin{tabular}{c}
\hline KeMAS 12 (2) (2017) xx-xx \\
Jurnal Kesehatan Masyarakat
\end{tabular}

\title{
MEAL PATTERN OF MALNUTRITION CHILDREN UNDER 5 YEARS AND RE- LATED FACTORS
}

\author{
Suherni $^{1 \bowtie}$, Fanjaniaina Sophia ${ }^{2}$, Asih Kuswardinah ${ }^{3}$ \\ ${ }^{1}$ Post Graduate Program, Universitas Negeri Semarang, Indonesia. \\ ${ }^{2}$ Conabex (Coordination Bourse Exterieur), Madagaskar \\ ${ }^{3}$ Post Graduate Program, Universitas Negeri Semarang, Indonesia
}

\begin{tabular}{l} 
Article Info \\
\hline Article History: \\
Submitted 19 October 2016 \\
Accepted 8 January 2016 \\
Published January 2017 \\
\hline Keywords: \\
Meal pattern; malnu- \\
trition; knowledge; \\
education; income. \\
\hline DOI \\
http://dx.doi.org/10.15294/ \\
kemas.v11i1.3521
\end{tabular}

\begin{abstract}
Malnutrition prevalence in Indonesia has increased from 2007 to 2013. Research was conducted on Kabupaten Brebes which rank 29 of 35 Kabupaten/City on Jawa Tengah province in malnutrition case and meal pattern is found as related factor. The research objective is to obtain malnutrition children under 5 years meal pattern and others related factors. Reseach was conducted in 2016 by quantitative approach and supported with qualitative datas. Sampling method by total sampling from 32 mother and children under 5 years with malnutrition status. Research instrument consist of questionnaire and food recall instrument accompanied with observation guide. The quantitative datas are analysed by descriptive method and chi square statistic test. Result shown most of malnutrition children under 5 years meal pattern is improper (75\%) and children under 5 years feeding is not proper to it's nutrition requirement. Whether the nutrition, quantity and frequention of the feeding. This is relation between level of knowledge, education, family income with meal pattern ( $p$ value $<0.005$ ) and no relation between numbers of family member with meal factor of malnutrition children under 5 years $(\mathrm{p}$ value $=1.00)$ at work region of Puskesmas Brebes. Respondent does not know proper food for children under 5 years, proper food for each children under 5 years age yet aware that the food must be cooked to produce soft texture.
\end{abstract}

\section{Introduction}

Nutritional problem on certain age will cause development problem on the future. Nutritional status influence children under 5 years development and intelligence (Fifi, 2006). Meanwhile, babysit way and nutritional status is highly related. On UNICEF frame, parenting style is indirect cause of malnutrition.

Malnutrition is one condition that experience insufficient nutrition or below average nutrition standard. On severe level, malnutrition can be harmed to the child due to physical disfunction such as hypothermia caused by thin fatty tissue, hypoglichemy and lack of electrolite and dehidration. If this phase is not quickly taken care of, it will affect child grow and development. Malnutrition can also influence brain and mind development. Brain development is vital since brain is important asset to be a quality human being (Ivanovic, 2008).

Malnutrition can be caused by direct factors like insufficient quantity and quality of meal consumed and disease. While indirect

\footnotetext{
Correspondece Address:

Program Paca Sarjana, Universitas Negeri Semarang

Email : suhemini@gmail.com
} 
factors are in house food availability, health behavior and health service. Others influence factors are poverty, low education, food availability and job oportunity (Pongou, 2006; Kamiya, 2011; Imdad, 2011).

Meal pattern is ways taken by someone or a group of people to choose the meal and consume it as a reaction of fisiology, psychology, culture and social common. An children under 5 years had difficulty with self-regulation specificly in meal. Children under 5 years's food consumption morely dependent to the caregiver. Baby feeding need to consider the timing, frequention, kind of food and preparation method. One of improper baby feeding is premature feeding can lead to disturbances in digesting system, such as diarhea, throw up and constipation (Cott, 2003). Baby feeding in Indonesia is more likely not proper with the age spesificly on villages. Research result indicated that vilagers in Indonesia commonly give banana (57.3\%) to the baby in below 4 months age.

Based on Basic Health Research result in 2013, there were $5.7 \%$ malnutrition children under 5 years, increase from $4.4 \%$ in 2007 and $4.9 \%$ in 2010 . Nutritional status monitoring result in 2014 on Brebes District prove that there are children under 5 years with Protein Energy Malnutrition consisted of malnutrition (1.04\%), nutritional deficiencis (5.62\%) from 20,710 children under 5 yearss, Brebes district is on 29 of 35 District/City in Central Java province. While for Public Health Care (Puskesmas) in Brebes district on 2015 as per May, children under 5 years with malnutrition recorded 24 cases $(1.62 \%)$, with most prevalency is 12 to 24 months age (56\%).

Based on preliminary study at Puskesmas Brebes, Brebes District by malnutrition children under 5 years mother interview, shown that they feed an inadequate intake of nutritional food and irregular meal pattern, most of the parents are only went throughelementary education. Each family within community on Puskesmas Brebes Brebes district usually has different meal consumption pattern and how they manage nutrition requirement fullfilment specificly for children under 5 years.

This research objective is to find out malnutrition children under 5 years meal pattern and relation between knowledge, education, income and number of family member with it in Puskesmas Brebes work region.

\section{Method}

Research approach is conducted quantitatively supported with qualitative datas. The population is all mothers of malnutrition children under 5 years on Puskesmas Brebes work region on December 2015. Sampling technique by total sampling 32 mothers. Independent variables in this research consist of mother's knowledge, mother's education, family income and numbers of family member, while dependent variable is children under 5 years meal pattern-

Research instruments consists of questionnaire that has been validity and reliability tested, used to obtain knowledge, education, income and number of family member data. Food frequency instrument is used to obtain meal pattern data, reviewed by food ingredients consumed, nutrition fact and meal frequency. The instruments are completed with observation guide to assist on decision making upon obtained datas. Qualitative datas obtained from 5 respondents, choosen based on purposive technique and the datas are used to complete research result review. The quantitative datas analyzed descriptively and by chisquare statistic test.

\section{Result and Discussion}

Meal pattern of malnutrition children under 5 years based on mother interview, found out that the mother does not know proper food ingredients for children under 5 years according to the age. All respondents said that the food ingredients for children under 5 years mainly is rice and must be cooked first. If the food does not made of rice, then it will be consider as snack. Meal frequency is 3 times a day, yet without snack and with soft texture.

Research result indicates quantitatively, most of children under 5 years meal pattern is not proper (75\%). This is based on 1) inadequate nutrition, calories and protein indicator on related age. 2) meal frequency are nearly the same (94\%) 3 times a day. Yet the amount is dependent on the children will, which are less than required. Since most of children under 5 years with malnutrition status are difficult to feed. The mother feel that she persuate enough 
and finally gave up to her children meal will. Snack time does not consider properly. Ideally children under 5 years got 3 meal time and 2 snack timein between.3) the nutrition consumed dominated by carbohydrate. Factors need to be considered to manage meal consumption such as age, weight, habit, preference of dislike, food acceptibility and tolerance are less considered. Meal given mostly alike. Rice, spinach or soup (consist of carrot, potato and cabbage) which bored the child. Children under 5 years in his grow and development are determined by food consumed daily. Required variety of meal, sufficient amount, nutrified and balance. Social Environmental factors with the availability of food ingredients will influence protein consumption level. As stated by Obaggy (2012), McKinnon (2009) and Glanz (2005), the environtment has significant effect to food consumtion as well as to children under 5 years life style and feeding pattern. The community will consume common food available in their environtment.

Mother has stronger bonds with her child and almost all parenting styles are under the mother's locus of control. As so, she has to have knowledge about child nutrition requirement, feed method and feed schedule so the child can grow and develop optimally. This is supported by Golan research (2004), mentioning mother is primary care taker of her children under 5 years offtenly describe as nutritional pattern and responsive parenting mostly depends on their knowledge of nutrition and health practice.

Knowledge level is mother capability or understanding of meal pattern related with aspects of food kinds, children under 5 years feed, kinds of nutrition and factors influence nutritional problems. Research result tested with chisquare indicates there is significant relation between knowledge and meal pattern of malnutrition children under 5 years on Puskesmas Brebes work region. It said that better knowledge lead to better meal pattern.

Research result is aligned with Nadaek (2011), on Pekan Dolok Masihul area, observe meal pattern and nutritional status of children under 5 years based on family characteristic show proper meal pattern by refer to energy and protein consumption found in family with mother has well knowledge of nutrition. On the opposite, malnutrition, short and under weight children under 5 years, found in family with mother has less knowledge of nutrition. Children under 5 years with well-nourished found on family with well consumption of energy and protein. Children under 5 years with malnutrition, stunting and under weight found on family with less consumption of energy and protein.

Putri (2012), said a mother role contribute significantly to family meal pattern since she prepare the food, arrange the menu, shop and cook and teach her children of meal order. Along with improvement of nutrition knowledge of the mother, it can be expected that she has improvement in choosing and planning the meal with various combination and proper with nutrition requirement. Nutrition knowledge level influence his behaviour and attitude in food choice and further to nutrition condition of one.

Someone with higher nutrition knowledge would consider kind and quantity of food to be consumed. Common people with less nutrition knowledge will rely only on his senses in choosing the food and disregard the nutrition aspect.

Education level is latest formal education had been through by respondent. In this research divided into elementary and middle school. Result showed there is significant relation between education level and children under 5 meal pattern on Puskesmas Brebes work region. With contigency coeffisient 0.516 indicate intermediate relation level. It mean higher education level lead to better meal pattern. In this case, respondent has sufficient formal education level so she has open mind and easily accepted good suggestion in taking care her baby and implicate to children under 5 year feed habit.

Result of mother with elementary education level mostly show poor nutritional intake children under five pattern (91.3\%), Respondents with middle school education level mostly have well-balanced meal children under five $(66.7 \%)$. This indicate more received information then more knowledge about health. Yet the knowledge does not certainly obtained by formal education. Elementary 
educated respondent with abundant health information about taking care of a baby during pregnancy check and well attention to health educator will influence her knowledge. As this research found out few mother with elementary education level has well-balanced meal (8.7\%) due to her knowledge from formal and informal education. Respondent can obtain the knowledge of proper children under 5 years meal pattern while she bring her child to health center for children (posyandu) or when to participate in counseling for maternal and child health.

Research result aligned with Aeni Nur (2009), stated mother capability in choose the ingredients, cook the food, and serve the meal is required to obtain well-nourished for children under 5 years. Mother practice in preparing the food is highly influenced by her knowledge level and attitude in choose the ingredients, cook the food, and serve well balanced meal indirectly improve children under 5 years nutrition status.

One vision and believe, also their knowledge in nutrition must be consider as part of reasons influencing their food consumption. By education, expected that food consumption and nutrition condition will be improved. Education is one of effort to improve personality and capability inside and outside school and a lifetime process. Education influence learn process. Higher education level will lead to one acceptance of information.

Family income is amount of work result earned by family to fulfill it's daily requirements.

From chi square test with Fisher's Exact Test, obtain $\mathrm{p}$ value $=0.010(\mathrm{p}<0.05)$. So it can be concluded that there is relation between family income with children under 5 years meal pattern on Puskesmas Brebes work region. Income is an important factor in it role to food quality. If family income increase then quality food availability will be reached.

Research result show most of low income respondent has improper meal pattern (91.3\%). Family income and community socio culture influence meal consumption pattern. Therefore, within a community with low income, nutrition improvement effort closely related with income improvement and human resources development effort. Income level determine kind of food to buy.However to obtain quality meal consumption, should be supported by well knowledge of nutritious food required by the body.

This result aligned with Berg (2006) stated there is relation between income and nutritional status. Because income level is a factor determine quantity and quality of food consumption. It has been agreed that income is a main factor determining meal menu quality. Low income lead to low consumption ability, so one can't affort to buy sufficient amount of food.

Family income level influence family consumption ability on food constructing family meal pattern. Commonly, by high income quantity and kind of food obtained by the family is tend to have better one (Lutfiana, 2010; Kamiya, 2011). High income open opportunity for a family to choose high nutrition food ingredients to fullfil family requirement, include their children under 5 years requirement. The result also indicate that though some families has low income, they have well-balanced meal malnut(8.7\%) due to sufficient knowledge of nutrition requirement and they alocate some of the income to get nutritious food consumption. Also due to mother creativity to cook and serve the meal for her family.

Number of family members is quantity of people in the family. Based on chi square test with Fisher's Exact Test, obtain $p$ value $=1.000$ ( $p>0.05)$ then it can be said that there is no relation between number of family members with children under 5 years meal pattern on Puskesmas Brebes work region. Number of children in a family does not influence meal pattern. Personal experience is differ one to another. Experience bring knowledge along with it. Based on the result, respondent with more than 2 children has experience in taking care of her children while a mother has one child will also take a good care of her child.

Respondents with one child mostly has improper meal pattern (73.3\%), new respondent has less experience in taking care of her child so need a guidance from experienced one. Environtment is one of the factors contributing to knowledge. Environtment give first influence to someone, where he can learn proper and improper things according to group nature. 
In the environtment, someone will obtain experiences that influence his way of thinking. Culture environtment related with habit, values or social capital in the community can also influence parenting styles for the children include their meal pattern (Woro, 2013; 2014). Traditions and habits as well as believes in the community are difficult to change (Garces, 2006). Salehi (2004), also concluded that culture influence how a mother serve meal/nutrition for her childer under 5 years.

Results are not aligned with Nadaek (2011), on Pekan Dolok Masihul area, researching description of meal pattern and nutritional status of children under 5 years based on family characteristc shown wellbalanced meal of the children viewed from energy and protein consumption found on small family ( $\leq 4$ people). While large family $(\geq 7$ people) show poor nutritional intake. As so, children under 5 years with well-nourished found on small family ( $\leq 4$ people). While children under 5 years with malnutrition, stunting and underwewight found on large family ( $\geq 7$ people).

\section{Conclusion}

Meal pattern of malnutrition children under 5 years on Puskesmas Brebes work region mostly improper (75\%). There are relation between level of knowledge, education level and family income with children under 5 years meal pattern on Puskesmas Brebes work region. While number of family member is unrelated variable to children under 5 years meal pattern.

Relation between education, knowledge and income actualy is a chained factors. Where education influence knowledge and someone quickly absorb and understand informations, include one about health and nutrition. On the other hand, education can determine kind of job someone got and lead to income amount. Yet the conditon is not a certain. Other factors influencing as well.

\section{Acknowledgement}

Gratitude to 1) Head of Health Department, Brebes District for the permission to conduct this research in the work region 2) Head of Puskesmas Brebes and staffs for the help and support during this research, especially on data collection 3) Involved mothers and families as research respondents 4) Health cadres on Puskesmas Brebes region who helped to give information related with research datas.

\section{References}

Aeni Nur. 2009. Pengaruh Pengetahuan Pengolahan Bahan Makanan dan Pemberian Makanan Tambahan terhadap Status Gizi Anak Batita di Kelurahan Krobokan Semarang Barat, Semarang : Universitas Negeri Semarang

Berg. 2006.. The Influence of Socio-Economic and Nurtitional Characteristics on Child Growth in Kwale District of Kenya. African Jurnal of Agriculture and Development.

Cott. 2003. Penyusunan dan Pengembangan Formularium,Farmasi Klinis, 311-315, Jakarta: PT Elex Media Komputindo Gramedia.

Dinas Kesehatan Provinsi Jateng. 2014. Profil Kesehatan Jawa Tengah 2013. Semarang: Dinkes Jawa Tengah.

Fifi. 2006. Hubungan Pola Asuh dengan Status Gizi Anak Batita di Kecamatan Kuranji Kelurahan Pasar Ambacang Kota Padang Tahun 2004. Jurnal Kesehatan Masyarakat

Garces IC, Scarinci Isabel C, Harrison Lynda. 2006. An Axamination of Sociocultural Factors Associated With Health and Health Care Seeking Among Latina Immigrants. Journal Immigrant Health, 8 : 377-385

Glanz K, Sallis J, Saelens B, Frank L. 2005. Healthy nutrition environments: concepts and measures. Am J Health Promot, 19: 330 -333.

Golan M, Crow S. 2004. Targeting parents exclusively in the treatment of childhood obesity: longterm results. Obesity Research, 12: 357-361.

Istiano. 2009. Analisis Faktor-faktor Yang Mempengaruhi Status Gizi Balita. Jurnal Berita Kedokteran Masyarakat, 25 (3): 150155

Ivanovic.,D, Rodrigues, Perez,H. 2008. Twelve-year Follow-up Study of The Impact of Nutritional Status at The Onset of Elementary School on Later Educational Situation of Chilean School-age Chieldren. European Journal of Clinical Nutrition, 62: 18-31

Imdad A, Yakoob M, Bhutta ZA. 2011. Impact of Maternal Education About Complementary Feeding and Provision of Complementary Foods on Child Growth in Developing Countries. BMC Public Health, 11(3)

Kamiya, Yusuke. 2011. Socioeconomic Determinants of Nutritional Status of Children in Lao PDR:: Effects of Household and Community Factors. J Health PopulNutr, 29(4): 339-348

McKinnon A, et al. 2009. Measures of the Food Environment A Compilation of the Literature, 1990-2007.Am J Prev. Med.; 36 
(4S): S124-S133.

Nadaek. 2011. pola makan dan status gizi anak balita berdasarkan karakteristik di Kelurahan Pekan Dolok Masihul. Kecamatan Dolok Masihul Kabupaten Serdang Bedagai tahun 2011.

OktiaWoro, Sunaryanto Lasmono T, Farida Eko. 2013. The Contribution of Cultural System in Toodler Parenting by Mother (In the Context of Nutritional Status). Research on Hummanities and Social Sciences, 3(6) : 105111

Oktia Woro, et al. 2014. Social Capital and Nutritional Status of Child Under 5 Years in Rural Indonesia and Thailand.Jurnal KEMAS, 10 (1) : 88-95

Obaggy J andEssery E. 2012. The food environment, eating out and body weight: A review of the evidence.Nutrition Insights, 49

Putri Anindita. 2012. Hubungan Tingkat Pendidikan Ibu, Pendapatan Keluarga, Kecukupan Protein dan Zinc Dengan Stunting (Pendek) Pada Balita Usia 6-35 Bulan Di Kecamatan Tembalang Kota Semarang. Jurnal Kesehatan Masyarakat, 1 (2): 617-626

Pongou R, Ezzati M \& Salomon JA. 2006. Household and Community Socioeconomic and
Environmental Determinants of Child Nutritional Status In Cameroon. BMC Public Health, 698

Raharjo Bambang B, Woro Oktia, Efa Nugroho, Berta Kalswahermawati. 2016. Local Potentials as Capital for Planning Nutrition Programs for Urban Fringe Areas in Developing Countries. Pakistan Journal of Nutrition: 1-8

Salehi M, Kimiagar SM, Shahbazi M, Mehrabi Y. 2004. Assessing the Impact of Nutrition Education on Growth Indices of Iranian Nomadic Children: An Application of A Modified Beliefs, Attitudes, Subjectivenorms and Enabling-factors Model. The British Journal of Nutrition, 91: 779 